\title{
Synthesis and biological evaluation of 3-arylcoumarins as potential anti-Alzheimer's disease agents
}

\author{
Jie Yang ${ }^{a, b, c, d}$, Pingping Zhang ${ }^{a, b, c, d}$, Yuheng Hu ${ }^{a, b, c, d}$, Teng Liu ${ }^{a, b, c, d}$, Jie Sun ${ }^{a, b, c, d}$ (D) and \\ Xiaojing Wang ${ }^{a, b, c, d}$
}

${ }^{a}$ School of Medicine and Life Sciences, University of Jinan-Shandong Academy of Medical Sciences, Jinan, China; ${ }^{\mathrm{b}}$ Institute of MateriaMedica, Shandong Academy of Medical Sciences, Jinan, China; ${ }^{C}$ Key Laboratory for Biotech-Drugs Ministry of Health, Jinan, China; ${ }^{d}$ Key Laboratory for Rare \& Uncommon Diseases of Shandong Province, Jinan, China

\section{ABSTRACT}

Alzheimer's disease, a neurodegenerative illness, has the extremely complex pathogenesis. Accumulating evidence indicates there is a close relationship between several enzymes and Alzheimer's disease. Various substituted 3-arylcoumarin derivatives were synthesised, and their in vitro activity, including cholinesterase inhibitory activity, monoamine oxidase inhibitory activity, and antioxidant activity were investigated. Most of the compounds exhibited high activity; therefore 3-arylcoumarin compounds have the potential as drug candidates for the treatment of Alzheimer's disease.
ARTICLE HISTORY

Received 10 December 2018 Revised 18 January 2019 Accepted 22 January 2019

\section{KEYWORDS}

3-Arylcoumarin; Alzheimer's disease; cholinesterase inhibitors; monoamine oxidase inhibitors; antioxidant activity

\section{Introduction}

Alzheimer's disease (AD) has become one of the major diseases that threatening the health of elder people in modern society. Alzheimer's disease, a chronic progressive neurodegenerative disease, usually starts slowly and worsens over time. The most common early symptom is difficulty in remembering recent events. As the disease advances, symptoms can include problems with language, disorientation, loss of motivation, not managing and so on ${ }^{1}$. Gradually, bodily functions are lost, ultimately leading to death. $A D$ is a refractory disease with complicated etiopathogenesis. Several hypotheses, such as cholinergic hypothesis, were proposed to explain the cause of the disease. The most currently available drug therapies were based on the cholinergic hypothesis, which proposes that $A D$ is caused by reduced synthesis of the neurotransmitter acetylcholine $(\mathrm{ACh})^{2}$.

The potential of acetylcholinesterase (AChE) inhibitors has been well explored and developed as an anti-AD drug ${ }^{3}$. There are currently five drugs used to treat $A D$ cognitive problems, four of which are AChE inhibitors (tacrine, donepezil, galantamine, rivastigmine). The AChE activity of AD patients decreased, but butyrylcholinesterase (BuChE) activity was stable or even increased; the ratio of $\mathrm{AChE}$ to BuChE changed, indicating that BuChE may act as a compensatory mechanism for ACh metabolism. Studies have shown that selective BuChE inhibitors are beneficial for cognitive dysfunction of $A D$, and dual $A C h E / B u C h E$ inhibition can maximise therapeutic efficacy ${ }^{4}$. Monoamine oxidase (MAO) is one of several enzymes that cause oxidative stress and dementia behaviour and psychological symptoms in AD. MAO-A inhibitors can be used as antidepressants and anxiolytics, while MAO-B inhibitors can be used alone or in combination to treat $A D$ and Parkinson's disease $^{5}$. Accumulating evidence shows that cholinesterase (ChE) and MAO are closely related to the disease symptoms and progression of AD. Many studies have identified the role of various ChE/MAO inhibitors in $A D$, while some showing positive results in clinical trials ${ }^{6}$.

3-Arylcoumarin refers to a class of compounds having a coumarin skeleton and having an aryl structure at the 3-position, which is rich in biological activity such as antioxidant ${ }^{7}$, anti-inflammatory $^{8}$, antitumour ${ }^{9}$, antiviral ${ }^{10}$, antifungal ${ }^{11}$, antidiabetic ${ }^{12}$, MAO inhibitory activity ${ }^{13,14}$, ChE inhibitory activity ${ }^{15}$ and so on. The aetiology of Alzheimer's disease is complex, and for this multi-faceted disease, the efficacy of multi-targeted drugs is better than that of single-targeted drugs. Coumarin compounds, as dual inhibitors, are promising compounds that control $\mathrm{AD}^{16-20}$. Patil et al. ${ }^{21}$ reviewed the synthesis and designed aspects of coumarin derivatives as $M A O$ inhibitors for $A D$, in which most 3-arylcoumarin compounds selectively inhibit MAO-B and give some guidance in modifying the structure. Wang et al. ${ }^{15}$ designed, synthesised, and evaluated a series of 6-substituted 3-arylcoumarin derivatives as dual $A C h E / M A O-B$ dual inhibitors for the treatment of $A D$, which provided meaningful information for further development of multifunctional drugs for AD treatment. Previous studies ${ }^{15,21-24}$ have designed coumarin derivatives as potential inhibitors of $\mathrm{MAO}$ and $\mathrm{ChE}$, and have achieved good results. These results encourage us to further explore the potential of coumarins as candidates for the treatment of $A D$.

CONTACT Jie Sun sunjie310@126.com; Xiaojing Wang xiaojing6@gmail.com S School of Medicine and Life Sciences, University of Jinan-Shandong Academy of Medical Sciences, Jinan 250062, Shandong, China

(C) 2019 The Author(s). Published by Informa UK Limited, trading as Taylor \& Francis Group.

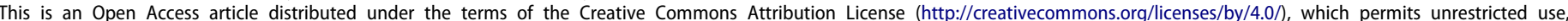
distribution, and reproduction in any medium, provided the original work is properly cited. 


\section{Experimental}

\subsection{Animals}

The $A B$ wild-type zebrafish was provided by Key Laboratory for Drug Screening Technology of Shandong Academy of Sciences. The zebrafish were cultured in an environment with a cycle of $14 \mathrm{~h}$ light and $10 \mathrm{~h}$ darkness, a pH of about 7.0, and a temperature of about $28{ }^{\circ} \mathrm{C}$. The healthy zebrafish were mated in a tank one day before the experiment, with a male to female ratio of 1:1. The separator was taken the next day and the fertilised eggs were collected $0.5 \mathrm{~h}$ later. The fertilised eggs were washed 3 times with aquaculture water, then disinfected with methylene blue solution, and transferred to clean culture water of about $28^{\circ} \mathrm{C}$ for light-control culture.

Wistar rat, weight 200-250 g, were obtained from Jinan Peng Yue Experimental Animal Co. (License number: SCXK (Lu) 2014-0007), Ltd. The animals were housed under standard laboratory conditions and maintained on a standard pellet diet and water ad libitum. All experiments involving living animals and their care were performed in strict accordance with the National Care and Use of Laboratory Animals by the National Animal Research Authority (China) and guidelines of Animal Care and Use issued by the University of Jinan Institutional Animal Care and Use Committee. The experiments were approved by the Institutional Animal Care and Use Committee of the School of Medicine and Life Sciences, University of Jinan. All efforts were made to minimise animal's suffering and to reduce the number of animals used.

\subsection{In vitro cholinesterase inhibitory activity}

The anticholinesterase activity of the 3-arylcoumarin compounds was determined by the method of Ellman et al. ${ }^{25}$ with slight modifications. AChE inhibitory activities were determined by AChE from electric eel (Macklin). BuChE inhibitory activities were determined by BuChE from horse serum (Aladdin). To a $10 \mathrm{ml}$ tube, $2.65 \mathrm{ml}$ of phosphate buffer solution $(0.1 \mathrm{M}, \mathrm{pH}=8.0), 100 \mu \mathrm{L}$ of 5,5-dithiobis-2-nitrobenzoic acid $(0.75 \mathrm{mM}$ in $0.1 \mathrm{M}$ phosphate buffer solution, $\mathrm{pH}=8.0$ ) were added sequentially, $50 \mu \mathrm{L}$ AChE solution $(0.2 \mathrm{U} / \mathrm{mL}$ in $0.1 \mathrm{M}$ phosphate buffer solution, $\mathrm{pH}=8.0)$, $100 \mu \mathrm{L}$ of different concentrations of the sample solution, shaken well, and incubated at $37^{\circ} \mathrm{C}$ for $5 \mathrm{~min}$. Then $100 \mu \mathrm{L}$ of substrate (1.5 $\mathrm{mM}$ in $0.1 \mathrm{M}$ phosphate buffer solution, $\mathrm{pH}=8.0$ ) were added, shaken well, and incubated at $37^{\circ} \mathrm{C}$ for $20 \mathrm{~min}$. After the reaction was completed, $1 \mathrm{ml}$ of sodium lauryl sulphate (4\%, SDS in water) was added. The absorbance at $412 \mathrm{~nm}$ of the samples was measured using a spectrophotometer, and the inhibition rate of cholinesterase and the $\mathrm{IC}_{50}$ value of each sample were calculated according to the formula. Determination of the inhibitory activity of BuChE is similar. The sample blank group replaced the substrate with PBS, and the blank group replaced the sample solution with a solvent. The sample solution was set to five concentration gradients and the experiment was repeated three times. Donepezil was used as a positive control.

Cholinesterase inhibitory effect $(\%)=\left[A_{0}-\left(A_{1}-A_{2}\right)\right] / A_{0} \times 100 \%$

where $A_{0}$ is the absorbance of blank group; $A_{1}$ is the absorbance of sample group; $A_{2}$ is the absorbance of sample blank group.

\subsection{In vitro monoamine oxidase inhibitory activity}

The MAO inhibitory activity of the 3-arylcoumarin compounds was determined by the method of Holt et al. $^{26}$ with slight modifications. The crude enzyme was extracted from the liver of $200-250 \mathrm{~g}$ of Wistar rats according to literature methods ${ }^{26-28}$. The crude enzyme protein content was determined by the Bradford/ method using a Bradford Protein Assay Kit (Beyotime). Forty microlitres of enzyme solution and $40 \mu \mathrm{L}$ of sample solution were added to a 96-well plate. The solution was then incubated at $37^{\circ} \mathrm{C}$ for $20 \mathrm{~min}$. One-twenty microlitres of the 4-(trifluoromethyl) benzylamine solution and $40 \mu \mathrm{L}$ of the chromogenic agent (1 mmol/L vanillic acid, $0.5 \mathrm{mmol} / \mathrm{L}$ 4-aminoantipyrine, $4 U / \mathrm{mL}$ horseradish peroxidase, $0.2 \mathrm{M} \mathrm{pH}=7.6 \mathrm{PBS}$ constant volume) were added subsequently, and incubated at $37^{\circ} \mathrm{C}$ for $90 \mathrm{~min}$. The absorbance was measured at $490 \mathrm{~nm}$ using a microplate reader, and the inhibition rate of $\mathrm{MAO}$ and the $\mathrm{IC}_{50}$ value of each sample were calculated according to the formula. The control group replaced the sample solution with PBS $(0.2 \mathrm{M}, \mathrm{pH}=7.6)$, the positive control replaced the sample with the positive drug, and the blank group replaced the substrate with PBS, and each group was measured three times in parallel to average.

$$
\begin{aligned}
& \text { Monoamineoxidase inhibitory effect (\%) } \\
& \quad=\left[\left(A_{C}-A_{B}\right)-\left(A_{S}-A_{S B}\right)\right] /\left(A_{C}-A_{B}\right) \times 100 \%
\end{aligned}
$$

where $A_{\mathrm{C}}$ is the absorbance of control group; $A_{\mathrm{B}}$ is the absorbance of blank group; $A_{S}$ is the absorbance of sample group; $A_{\mathrm{SB}}$ is the absorbance of sample blank group.

\subsection{In vitro antioxidant activity}

The total antioxidant capacity of the 3-arylcoumarin compounds was measured by the FRAP (the Ferric Reducing Ability of Plasma) assay of Benzie et al. ${ }^{29}$ with slight modifications. This method is based on the reduction of colourless Fe(III)-TPTZ(2,4,6-Tris(2-pyridyl)-s-triazine) complex to coloured Fe(II)-TPTZ complex by the compounds. FRAP working solution $(300 \mathrm{mmol} / \mathrm{L}$ acetate buffer, $10 \mathrm{mmol} / \mathrm{L} \mathrm{TPTZ}, 20 \mathrm{mmol} / \mathrm{LFeCl}_{3}$ ) was ready to use. $A$ hundred microlitres of the sample solution was added to $3 \mathrm{ml}$ of FRAP reagent and then incubated at $37^{\circ} \mathrm{C}$ for $15 \mathrm{~min}$. The experiments were repeated for three times. The absorbance was measured at $593 \mathrm{~nm}$ to clarify the changes. The standard curve was drawn with $\mathrm{FeSO}_{4}$ as standard material, and the regression equation was obtained. With $1.0 \mathrm{mmol} / \mathrm{L} \mathrm{FeSO}_{4}$ as standard, the antioxidant activity of the sample is expressed in millimoles of $\mathrm{Fe}_{2} \mathrm{SO}_{4}$ required to achieve the same absorbance.

\subsection{Zebrafish behavioural experiment}

The experimental sample group and the blank control group were set in a 48-well plate, and $0.5 \mathrm{ml}$ of aquaculture water and a juvenile fish that developed to $72 \mathrm{hpf}$ (hours post fertilisation) were added to each well. Eight juvenile fish were set up for each experimental group. Compounds 2, 20, 22 were set at four different concentrations of $10 \mu \mathrm{g} / \mathrm{ml}, 50 \mu \mathrm{g} / \mathrm{ml}, 100 \mu \mathrm{g} / \mathrm{ml}$, and $1000 \mu \mathrm{g} /$ $\mathrm{ml}$. The 48-well plate was placed in the dark box of the zebrafish behavioural analysis system. The fish were adapted to the environment for $10 \mathrm{~min}$ before the experiment. The zeblab software (Viewpoint, Lyon, France) was used to collect the trajectories of the juveniles in each group within $30 \mathrm{~min}$, recorded every $5 \mathrm{~min}$, and the total parade distance and parade time were exported by software. The average distance of each group of fish parades was calculated. 


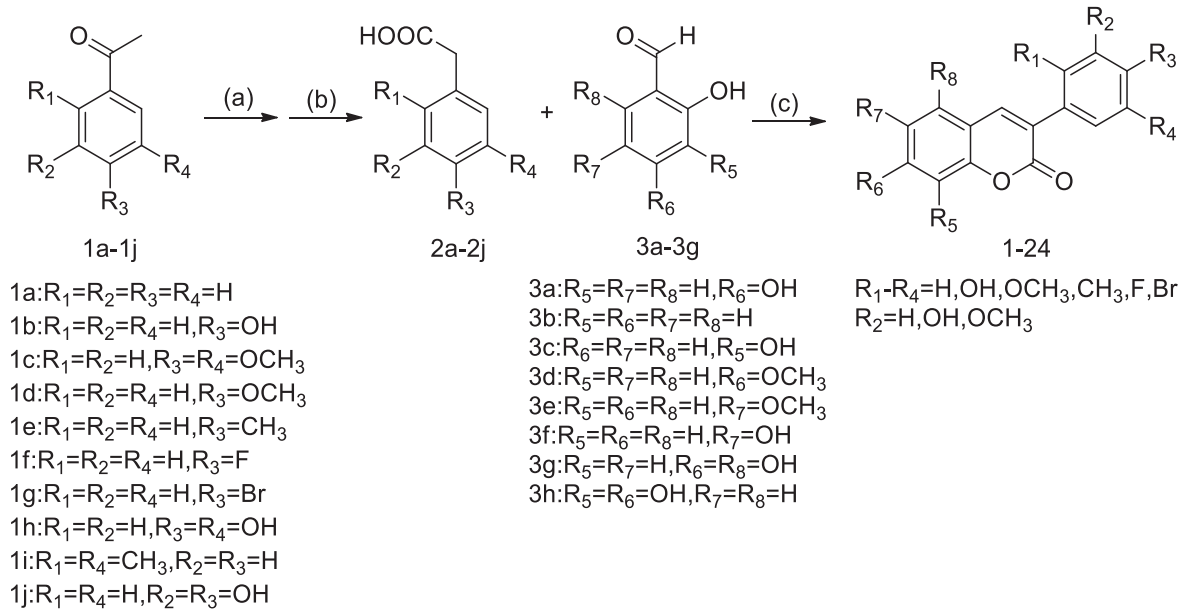

Scheme 1. General synthetic route to 3-arylcoumarin, reagents, and conditions: (a) sulphur, p-toluenesulfonic acid, morpholine, $120^{\circ} \mathrm{C}$; (b) sodium hydroxide solution, tetrabutylammonium bromide, $100^{\circ} \mathrm{C}$; (c) acetic anhydride, triethylamine, $112^{\circ} \mathrm{C}$.

\subsection{Statistical analysis}

Data were shown as mean \pm SD Differences between individual groups were analysed by using ANOVA followed by Dunnett's test. A difference with a $p$ value of $<.05$ was considered to be significant.

\section{Results and discussion}

\subsection{Chemistry}

The synthetic methods and chemicals previously reported by our research group were used ${ }^{30}$. The synthetic route was summarised in Scheme 1. The substituted phenylacetic acid is synthesised by substituting acetophenone, then the 3-arylcoumarin structure skeleton is synthesised by Perkin reaction with substituted salicylaldehyde under the action of triethylamine and acetic anhydride, and the target compound is obtained by acid hydrolysis (Table 1). Details on the chemical and spectroscopic characterisations of compounds were described in the references.

\subsection{Biological evaluation}

\subsubsection{In vitro cholinesterase inhibitory activity}

$\mathrm{AChE}$ is associated with neurons and axons, and is primarily responsible for $\mathrm{ACh}$ hydrolysis and termination. Studies have shown that long-term AChE inhibitor treatment can prevent the progression of cognitive dysfunction in patients with $A D^{31-33}$. In the $A D$ brain, BuChE may play a beneficial role by restoring cholinergic activity and/or by restoring $\mathrm{AChE} / \mathrm{BuChE}$ activity ratio ${ }^{34}$. The AChE/BuChE inhibitory activity of all compounds was determined by the method of Ellman ${ }^{25}$, and donepezil was used as a reference compound in this assay. All the compounds were tested AChE/BuChE inhibitory activity in vitro, as shown in Table 2, most compounds presented inhibitory activity for AChE/BuChE. Most of the compounds exhibited moderate AChE inhibitory activity. Notably, compound $22\left(\mathrm{IC}_{50}=3.04 \pm 0.32 \mu \mathrm{M}\right)$ had relatively strong activity, which displayed weaker capacity than donepezil, and compound $\mathbf{2 0}$ exhibited selective AChE inhibitory activity. Only compound $7\left(\mathrm{IC}_{50}=2.76 \pm 0.57 \mu \mathrm{M}\right)$ had stronger BuChE activity than donepezil, and compounds 2, 5, 10 exhibited selective BuChE inhibitory activity. The results showed that 3-arylcoumarins with a $R_{5}, R_{6}$-dihydroxy group has a significantly stronger inhibitory activity than the $\mathrm{R}_{6}{ }^{-}$or $\mathrm{R}_{5}$-position mono-substituted
Table 1. Compounds 1-24.

\begin{tabular}{|c|c|c|c|c|c|c|c|c|}
\hline Product & $\mathrm{R}_{1}$ & $\mathrm{R}_{2}$ & $\mathrm{R}_{3}$ & $\mathrm{R}_{4}$ & $\mathrm{R}_{5}$ & $\mathrm{R}_{6}$ & $\mathrm{R}_{7}$ & $\mathrm{R}_{8}$ \\
\hline 1 & $\mathrm{H}$ & $\mathrm{H}$ & $\mathrm{H}$ & $\mathrm{H}$ & $\mathrm{H}$ & $\mathrm{OH}$ & $\mathrm{H}$ & $\mathrm{H}$ \\
\hline 2 & $\mathrm{H}$ & $\mathrm{H}$ & $\mathrm{H}$ & $\mathrm{H}$ & $\mathrm{OH}$ & $\mathrm{H}$ & $\mathrm{H}$ & $\mathrm{H}$ \\
\hline 3 & $\mathrm{H}$ & $\mathrm{H}$ & $\mathrm{H}$ & $\mathrm{H}$ & $\mathrm{OH}$ & $\mathrm{OH}$ & $\mathrm{H}$ & $\mathrm{H}$ \\
\hline 4 & $\mathrm{H}$ & $\mathrm{H}$ & $\mathrm{OH}$ & $\mathrm{H}$ & $\mathrm{H}$ & $\mathrm{OH}$ & $\mathrm{H}$ & $\mathrm{H}$ \\
\hline 5 & $\mathrm{H}$ & $\mathrm{H}$ & $\mathrm{OH}$ & $\mathrm{H}$ & $\mathrm{H}$ & $\mathrm{H}$ & $\mathrm{H}$ & $\mathrm{H}$ \\
\hline 6 & $\mathrm{H}$ & $\mathrm{H}$ & $\mathrm{OH}$ & $\mathrm{H}$ & $\mathrm{OH}$ & $\mathrm{H}$ & $\mathrm{H}$ & $\mathrm{H}$ \\
\hline 7 & $\mathrm{H}$ & $\mathrm{H}$ & $\mathrm{OH}$ & $\mathrm{H}$ & $\mathrm{H}$ & $\mathrm{OH}$ & $\mathrm{H}$ & $\mathrm{OH}$ \\
\hline 8 & $\mathrm{H}$ & $\mathrm{H}$ & $\mathrm{OH}$ & $\mathrm{H}$ & $\mathrm{OH}$ & $\mathrm{OH}$ & $\mathrm{H}$ & $\mathrm{H}$ \\
\hline 9 & $\mathrm{H}$ & $\mathrm{H}$ & $\mathrm{OH}$ & $\mathrm{H}$ & $\mathrm{H}$ & $\mathrm{OCH}_{3}$ & $\mathrm{H}$ & $\mathrm{H}$ \\
\hline 10 & $\mathrm{H}$ & $\mathrm{H}$ & $\mathrm{OH}$ & $\mathrm{H}$ & $\mathrm{H}$ & $\mathrm{H}$ & $\mathrm{OCH}_{3}$ & $\mathrm{H}$ \\
\hline 11 & $\mathrm{H}$ & $\mathrm{H}$ & $\mathrm{OH}$ & $\mathrm{H}$ & $\mathrm{H}$ & $\mathrm{H}$ & $\mathrm{OH}$ & $\mathrm{H}$ \\
\hline 12 & $\mathrm{H}$ & $\mathrm{H}$ & $\mathrm{OCH}_{3}$ & $\mathrm{OCH}_{3}$ & $\mathrm{OH}$ & $\mathrm{OH}$ & $\mathrm{H}$ & $\mathrm{H}$ \\
\hline 13 & $\mathrm{H}$ & $\mathrm{H}$ & $\mathrm{OCH}_{3}$ & $\mathrm{H}$ & $\mathrm{H}$ & $\mathrm{OH}$ & $\mathrm{H}$ & $\mathrm{H}$ \\
\hline 14 & $\mathrm{H}$ & $\mathrm{H}$ & $\mathrm{OCH}_{3}$ & $\mathrm{H}$ & $\mathrm{OH}$ & $\mathrm{H}$ & $\mathrm{H}$ & $\mathrm{H}$ \\
\hline 15 & $\mathrm{H}$ & $\mathrm{H}$ & $\mathrm{OCH}_{3}$ & $\mathrm{H}$ & $\mathrm{OH}$ & $\mathrm{OH}$ & $\mathrm{H}$ & $\mathrm{H}$ \\
\hline 16 & $\mathrm{H}$ & $\mathrm{H}$ & $\mathrm{CH}_{3}$ & $\mathrm{H}$ & $\mathrm{H}$ & $\mathrm{OH}$ & $\mathrm{H}$ & $\mathrm{H}$ \\
\hline 17 & $\mathrm{H}$ & $\mathrm{H}$ & $\mathrm{CH}_{3}$ & $\mathrm{H}$ & $\mathrm{OH}$ & $\mathrm{OH}$ & $\mathrm{H}$ & $\mathrm{H}$ \\
\hline 18 & $\mathrm{H}$ & $\mathrm{H}$ & $\mathrm{F}$ & $\mathrm{H}$ & $\mathrm{H}$ & $\mathrm{OH}$ & $\mathrm{H}$ & $\mathrm{H}$ \\
\hline 19 & $\mathrm{H}$ & $\mathrm{H}$ & $\mathrm{F}$ & $\mathrm{H}$ & $\mathrm{OH}$ & $\mathrm{OH}$ & $\mathrm{H}$ & $\mathrm{H}$ \\
\hline 20 & $\mathrm{H}$ & $\mathrm{H}$ & $\mathrm{Br}$ & $\mathrm{H}$ & $\mathrm{H}$ & $\mathrm{H}$ & $\mathrm{H}$ & $\mathrm{H}$ \\
\hline 21 & $\mathrm{H}$ & $\mathrm{H}$ & $\mathrm{Br}$ & $\mathrm{H}$ & $\mathrm{OH}$ & $\mathrm{OH}$ & $\mathrm{H}$ & $\mathrm{H}$ \\
\hline 22 & $\mathrm{H}$ & $\mathrm{H}$ & $\mathrm{OH}$ & $\mathrm{OH}$ & $\mathrm{OH}$ & $\mathrm{OH}$ & $\mathrm{H}$ & $\mathrm{H}$ \\
\hline 23 & $\mathrm{CH}_{3}$ & $\mathrm{H}$ & $\mathrm{H}$ & $\mathrm{CH}_{3}$ & $\mathrm{OH}$ & $\mathrm{OH}$ & $\mathrm{H}$ & $\mathrm{H}$ \\
\hline 24 & $\mathrm{H}$ & $\mathrm{OH}$ & $\mathrm{OH}$ & $\mathrm{H}$ & $\mathrm{H}$ & $\mathrm{OH}$ & $\mathrm{H}$ & $\mathrm{H}$ \\
\hline
\end{tabular}

3-arylcoumarin, and 3-arylcoumarin having a $R_{5}, R_{6}$-dihydroxy group all showed high AChE inhibitory activity. However, there is no significant tendency for the inhibitory activity of BuChE.

\subsubsection{In vitro monoamine oxidase inhibitory activity}

MAO plays an important role in neurotransmitter inactivation, and MAO dysfunction is considered to be the cause of many mental and neurological diseases. MAO plays an important role in AD pathology, and the progress of $A D$ has a close correlation with MAO activity $^{35,36}$. All the synthesised compounds were evaluated for their MAO inhibitory activity in the way of $\mathrm{Holt}^{26}$ by references. The selective MAO-B inhibitor rasagiline was used as a reference compound in this assay. The MAO used in the experiment was selfmade. The protein content standard curve was drawn according to the absorbance of the protein standards at different concentrations at $595 \mathrm{~nm}$, and then the crude enzyme protein content was obtained by a regression equation according to the absorbance of the crude enzyme. The crude enzyme obtained was $0.157 \mathrm{mg}$ per $\mathrm{mg}$ of protein. Nearly half of the compounds showed MAO-B inhibitory activity. Among them, Compound $\mathbf{2 2}$ had the strongest 
Table 2. Biological evaluation in vitro.

\begin{tabular}{|c|c|c|c|c|}
\hline \multirow[b]{2}{*}{ Product } & \multicolumn{3}{|c|}{$\mathrm{IC}_{50}$ value $(\mu \mathrm{M})$} & \multirow{2}{*}{$\begin{array}{l}\text { FRAP value }(\mathrm{mmol} / \mathrm{g}) \\
\text { Antioxidant activity }\end{array}$} \\
\hline & AChE inhibitory activity & BuChE inhibitory activity & MAO-B inhibitory activity & \\
\hline 1 & $78.49 \pm 2.84$ & $44.82 \pm 2.35$ & $>700$ & $0.51 \pm 0.09$ \\
\hline 2 & $>100$ & $13.06 \pm 0.03$ & $>700$ & $0.16 \pm 0.05$ \\
\hline 3 & $17.97 \pm 1.13$ & $16.15 \pm 2.18$ & $73.45 \pm 11.97$ & $15.43 \pm 0.19$ \\
\hline 4 & $105.42 \pm 2.92$ & $34.71 \pm 1.87$ & $>700$ & $7.73 \pm 0.12$ \\
\hline 5 & $>100$ & $14.39 \pm 1.94$ & $>700$ & $0.42 \pm 0.01$ \\
\hline 6 & $68.25 \pm 0.72$ & $21.17 \pm 0.65$ & $>700$ & $0.66 \pm 0.08$ \\
\hline 7 & $16.39 \pm 0.19$ & $2.76 \pm 0.57$ & $204.61 \pm 6.92$ & $2.29 \pm 0.02$ \\
\hline 8 & $13.13 \pm 1.35$ & $18.86 \pm 0.43$ & $65.75 \pm 4.61$ & $10.51 \pm 0.23$ \\
\hline 9 & $100.59 \pm 2.02$ & $30.14 \pm 3.06$ & $>700$ & $0.67 \pm 0.04$ \\
\hline 10 & $>100$ & $10.57 \pm 0.85$ & $>700$ & $1.47 \pm 0.04$ \\
\hline 11 & $40.37 \pm 2.09$ & $75.60 \pm 4.01$ & $>700$ & $0.41 \pm 0.08$ \\
\hline 12 & $8.45 \pm 0.16$ & $24.81 \pm 3.81$ & $63.36 \pm 4.04$ & $11.75 \pm 0.12$ \\
\hline 13 & $42.44 \pm 3.16$ & $70.70 \pm 5.75$ & $>700$ & $0.61 \pm 0.11$ \\
\hline 14 & $84.57 \pm 1.67$ & $46.35 \pm 6.78$ & $503.05 \pm 12.56$ & $2.98 \pm 0.22$ \\
\hline 15 & $13.31 \pm 2.26$ & $26.53 \pm 0.98$ & $562.06 \pm 7.13$ & $10.40 \pm 0.48$ \\
\hline 16 & $82.81 \pm 1.43$ & $21.82 \pm 2.54$ & $>700$ & $0.35 \pm 0.05$ \\
\hline 17 & $12.58 \pm 1.28$ & $13.15 \pm 0.35$ & $>700$ & $13.16 \pm 0.68$ \\
\hline 18 & $74.29 \pm 3.72$ & $29.27 \pm 4.41$ & $>700$ & $0.38 \pm 0.07$ \\
\hline 19 & $27.12 \pm 0.66$ & $25.76 \pm 3.61$ & $231.62 \pm 17.19$ & $12.75 \pm 0.65$ \\
\hline 20 & $19.21 \pm 0.68$ & $>100$ & $>700$ & $0.42 \pm 0.06$ \\
\hline 21 & $8.75 \pm 0.63$ & $20.25 \pm 1.60$ & $>700$ & $14.64 \pm 0.53$ \\
\hline 22 & $3.04 \pm 0.32$ & $8.37 \pm 0.68$ & $27.03 \pm 0.50$ & $41.42 \pm 0.35$ \\
\hline 23 & $13.74 \pm 0.32$ & $9.92 \pm 0.54$ & $>700$ & $12.84 \pm 0.13$ \\
\hline 24 & $30.90 \pm 1.27$ & $70.92 \pm 4.22$ & $330.04 \pm 6.49$ & $8.41 \pm 0.11$ \\
\hline Donepezil & $0.021 \pm 0.001$ & $4.10 \pm 0.18$ & & \\
\hline Rasagiline & & & $0.125 \pm 0.005$ & \\
\hline Ascorbic Acid & & & & $3.79 \pm 0.08$ \\
\hline
\end{tabular}

Each value represents the mean \pm SD $(n=3)$.
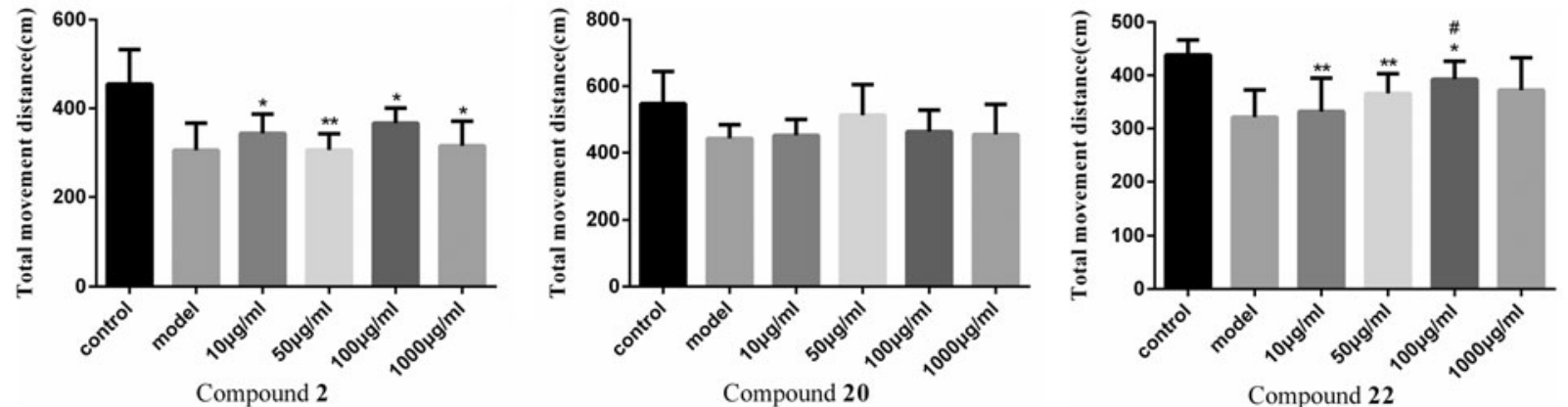

Figure 1. Effect of compounds 2, 20, 22 on the average total distance of zebrafish juveniles. (Compared with the control group, * $p<.05$ had a significant difference, ${ }^{* *} p<.01$ had a very significant difference; compared with the model group, ${ }^{\#} p<.05$ had a significant difference, ${ }^{\# \#} p<.01$ had a very significant difference).

inhibitory activity $\left(\mathrm{IC}_{50}=27.03 \pm 0.50 \mu \mathrm{M}\right)$, which was weaker than the positive control drug rasagiline $\left(\mathrm{IC}_{50}=0.125 \pm 0.005 \mu \mathrm{M}\right)$. The experimental results show that the 3-arylcoumarin compounds with $\mathrm{R}_{5}, \mathrm{R}_{6}$-dihydroxy group have better MAO inhibitory activity, indicating that $R_{5}, R_{6}$-dihydroxyl is very important for inhibiting MAO.

\subsubsection{In vitro antioxidant activity}

Oxidative damage is involved in the pathogenesis of neuronal degeneration in $A D$, which may represent a potential therapeutic target for slowing the progression of $A D$ or possibly preventing the onset of $A D^{37}$. Oxidative stress is a key feature in determining $A D$. All the synthesised compounds were evaluated for their antioxidant activities by means of the Ferric Reducing Ability of Plasma. Vitamin $C$ was used as a reference in this assay. The standard curve was drawn with $\mathrm{FeSO}_{4}$ as standard material, and the antioxidant capacity of the sample is expressed as FRAP value. As shown in Table 2, most of the compounds exhibited moderate to excellent antioxidant activities, even better than vitamin C. Especially, the FRAP values of compounds 3, 8, 12, 15, 17, 19, 21, 22, 23 were from $10.40 \pm 0.48$ to $41.42 \pm 0.35 \mathrm{mmol} / \mathrm{g}$, which were $3-11$ folds of the value of vitamin C (FRAP value $=3.79 \pm 0.08 \mathrm{mmol} / \mathrm{g}$ ). Compound 22 (FRAP value $=41.42 \pm 0.35 \mathrm{mmol} / \mathrm{g}$ ) has the strongest antioxidant capacity. The antioxidant capacity of the compound is related to the position and number of hydroxyl substitution, and the $R_{5}, R_{6}$-dihydroxy substituted compound has a strong antioxidant capacity.

\subsubsection{Zebrafish behavioural experiment}

To investigate the toxicity of compounds to zebrafish, the death and deformity of zebrafish were observed. Treatment in the blank group, $10,50,100,1000 \mu \mathrm{g} / \mathrm{ml}$ group for three days did not cause malformation and death of zebrafish. Healthy zebrafish were $\mathrm{AlCl}_{3}$ inducted after $72 \mathrm{~h}$ of fertilisation to construct a model of zebrafish Alzheimer's disease. Compound $\mathbf{2}$ is a selective BuChE inhibitor and Compound $\mathbf{2 0}$ is a selective AChE inhibitor that did not show significant effects in zebrafish behavioural experiments. Compound $\mathbf{2 2}$ is not only a dual ChE inhibitor but also a MAO-B inhibitor, which exhibits certain effects in zebrafish behavioural 


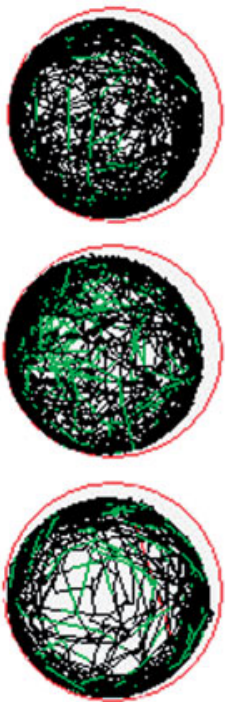

Control
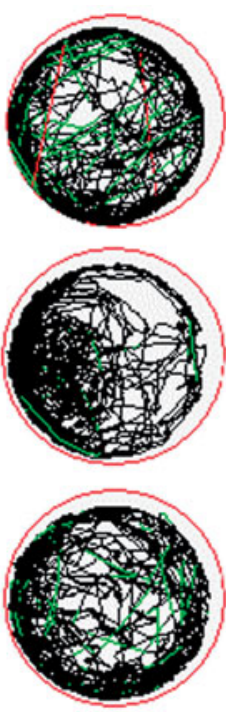

Model
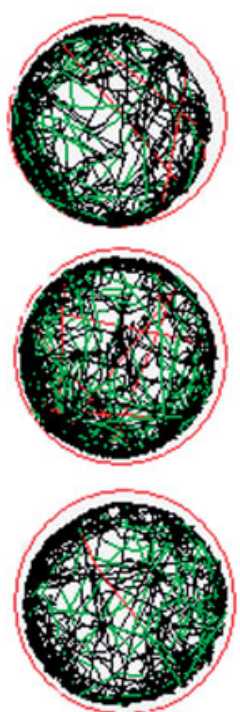

$10 \mu \mathrm{g} / \mathrm{ml}$
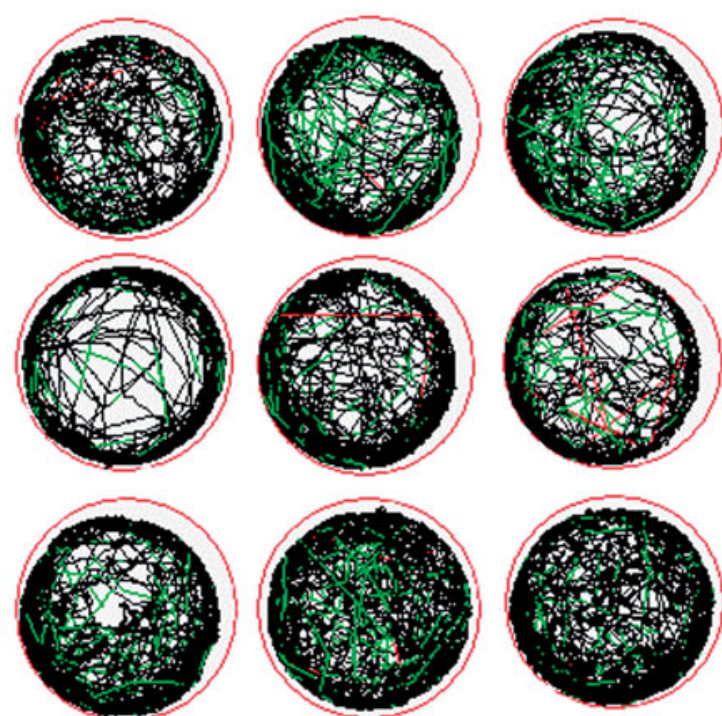

$50 \mu \mathrm{g} / \mathrm{ml}$

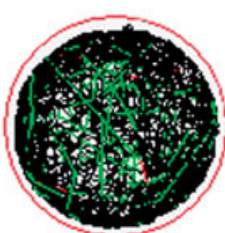

$100 \mu \mathrm{g} / \mathrm{ml}$

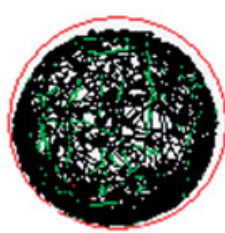

$1000 \mu \mathrm{g} / \mathrm{ml}$

Figure 2. Statistical graph of the total trajectory of zebrafish juveniles exposed to different concentrations of compound 22 for $72 \mathrm{hpf}$.

experiments. In the range of $10-100 \mu \mathrm{g} / \mathrm{ml}$, the total distance of zebrafish movement increases with the concentration of the compound increases. However, the high doses of compounds might cut down the movement distance of zebrafish (Figures 1 and 2).

\section{Conclusions}

We continue to study the pharmacological activities of 3-arylcoumarins synthesised by our research group. All the synthesised compounds were evaluated for their antioxidant activities in the way of the Ferric Reducing Ability of Plasma. Most compounds demonstrated moderate to high activity, among which compound 22 with several hydroxyl groups showed an excellent activity in this aspect. According to in vitro ChE inhibitory and MAO inhibitory test results, we selected selective $A C h E$ inhibitory compound 20, selective BuChE inhibitory compound 2, and dual ChE and MAO inhibitory compound $\mathbf{2 2}$ to study their anti-AD activity in vivo. Notably, compound $\mathbf{2 2}$ showed a certain effect in vivo experiments. Multi-target anti-AD compounds can modulate multiple signalling pathways or targets associated with $A D$, potentially producing significant clinical effects.

\section{Ethical statement}

All experiments involving living animals and their care were performed in strict accordance with the National Care and Use of Laboratory Animals by the National Animal Research Authority (China) and guidelines of Animal Care and Use issued by the University of Jinan Institutional Animal Care and Use Committee. The experiments were approved by the Institutional Animal Care and Use Committee of the School of Medicine and Life Sciences, University of Jinan. All efforts were made to minimise animal's suffering and to reduce the number of animals used.

\section{Disclosure statement}

No potential conflict of interest was reported by the authors.

\section{Funding}

The authors are grateful to support from the Science and Technology Research Programme of Shandong Academy of Medical Sciences (2017-16), Shandong Provincial Natural Science Foundation [ZR2018LH021] and the Innovation Project of Shandong Academy of Medical Sciences.

\section{ORCID}

Jie Sun (D) http://orcid.org/0000-0003-0552-9061

\section{References}

1. Burns A, lliffe S. Alzheimer's disease. BMJ 2009;338:b158.

2. Francis PT, Palmer AM, Snape $M$, et al. The cholinergic hypothesis of Alzheimer's disease: a review of progress. J Neurol Neurosurg Psychiatry 1999;66:137-47.

3. Singh M, Kaur M, Kukreja $\mathrm{H}$, et al. Acetylcholinesterase inhibitors as Alzheimer therapy: from nerve toxins to neuroprotection. Eur J Med Chem 2013;70:165-88.

4. Furukawa-Hibi $\mathrm{Y}$, Alkam $\mathrm{T}$, Nitta $\mathrm{A}$, et al. Butyrylcholinesterase inhibitors ameliorate cognitive dysfunction induced by amyloid- $\beta$ peptide in mice. Behav Brain Res 2011;225:222-9.

5. Riederer P, Lachenmayer L, Laux G. Clinical applications of MAO-inhibitors. Curr Med Chem 2004;11:2033-43.

6. Knez $D$, Sova $M$, Košak $U$, et al. Dual inhibitors of cholinesterases and monoamine oxidases for Alzheimer's disease. Future Med Chem 2017;9:811-32.

7. Maria JM, Pérez-Cruz F, Saleta VR, et al. Remarkable antioxidant properties of a series of hydroxy-3-arylcoumarins. Bioorg Med Chem 2013;21:3900-6.

8. Pu WC, Lin Y, Zhang JS, et al. 3-Arylcoumarins: synthesis and potent anti-inflammatory activity. Bioorg Med Chem Lett 2014;24:5432-4.

9. Zhao HP, Yan B, Peterson LB, et al. 3-Arylcoumarin derivatives manifest anti-proliferative activity through $\mathrm{Hsp} 90$ inhibition. ACS Med Chem Lett 2012;3:327-31. 
10. Nichols DB, Leão RAC, Basu A, et al. Evaluation of coumarin and neoflavone derivatives as HCV NS5B polymerase inhibitors. Chem Biol Drug Des 2013;81:607-14.

11. ElSeedi HR. Antimicrobial Arylcoumarins from Asphodelus microcarpus. J Nat Prod 2007;70:118-20.

12. Wang B, Li N, Liu T, et al. Synthesis and biological evaluation of novel neoflavonoid derivatives as potential antidiabetic agents. RSC Adv 2017;7:34448-60.

13. Orhan IE, Gulcan HO. Coumarins: auspicious cholinesterase and monoamine oxidase inhibitors. Curr Top Med Chem 2015;15:1673-82.

14. Secci D, Carradori S, Bolasco A, et al. Synthesis and selective human monoamine oxidase inhibition of 3-carbonyl, 3-acyl, and 3-carboxyhydrazido coumarin derivatives. Eur J Med Chem 2011;46:4846-52.

15. Wang ZM, Li XM, Xue GM, et al. Synthesis and evaluation of 6-substituted 3-arylcoumarin derivatives as multifunctional acetylcholinesterase/monoamine oxidase B dual inhibitors for the treatment of Alzheimer's disease. RSC Adv 2015;5: 104122-37.

16. Anand $P$, Singh B, Singh N. A review on coumarins as acetylcholinesterase inhibitors for Alzheimer's disease. Bioorg Med Chem 2012;20:1175-80.

17. Pisani $L$, Farina $R$, Catto $M$, et al. Exploring basic tail modifications of coumarin-based dual acetylcholinesterase-monoamine oxidase B inhibitors: identification of water-soluble, brain-permeant neuroprotective multitarget agents. J Med Chem 2016;59:6791-806.

18. Najafi Z, Mahdavi M, Saeedi M, et al. Novel tacrine-coumarin hybrids linked to 1,2,3-triazole as anti-Alzheimer's compounds: in vitro and in vivo biological evaluation and docking study. Bioorg Chem 2019;83:303-16.

19. Yang HL, Cai P, Liu QH, et al. Design, synthesis and evaluation of coumarin-pargyline hybrids as novel dual inhibitors of monoamine oxidases and amyloid- $\beta$ aggregation for the treatment of Alzheimer's disease. Eur J Med Chem 2017;138: 715-28.

20. Pisani L, Farina R, Soto-Otero R, et al. Searching for multi-targeting neurotherapeutics against Alzheimer's: discovery of potent AChE-MAO B inhibitors through the decoration of the 2H-Chromen-2-one structural motif. Molecules 2016;21: 362.

21. Patil PO, Bari SB, Firke SD, et al. A comprehensive review on synthesis and designing aspects of coumarin derivatives as monoamine oxidase inhibitors for depression and Alzheimer's disease. Bioorg Med Chem 2013;21:2434-50.

22. Matos MJ, Janeiro P, González Franco RM, et al. Synthesis, pharmacological study and docking calculations of new benzo[f] coumarin derivatives as dual inhibitors of enzymatic systems involved in neurodegenerative diseases. Future Med Chem 2014;6:371-83.

23. Brühlmann C, Ooms F, Carrupt PA, et al. Coumarins derivatives as dual inhibitors of acetylcholinesterase and monoamine oxidase. J Med Chem 2001;44:3195-8.
24. Alipour M, Khoobi M, Nadri $H$, et al. Synthesis of some new 3-coumaranone and coumarin derivatives as dual inhibitors of acetyl- and butyrylcholinesterase. Arch Pharm 2013;44: 577-87.

25. Ellman GL, Courtney KD, Andres V, et al. A new and rapid colorimetric determination of acetylcholinesterase activity. Biochem Pharmacol 1961;7:88-95.

26. Holt A, Sharman DF, Baker GB, et al. A continuous spectrophotometric assay for monoamine oxidase and related enzymes in tissue homogenates. Anal Biochem 1997;244: 384-92.

27. Youdim MBH, Gross A, Finberg JPM. Rasagiline [N-propargyl$1 \mathrm{R}(+)$-aminoindan], a selective and potent inhibitor of mitochondrial monoamine oxidase B. Br J Pharmacol 2001;132: $500-6$.

28. Stafford Gl, Pedersen PD, Jäger AK, et al. Monoamine oxidase inhibition by southern African traditional medicinal plants. S Afr J. Bot 2007;73:384-90.

29. Benzie IFF, Strain JJ. The Ferric Reducing Ability of Plasma (FRAP) as a measure of "Antioxidant Power": the FRAP assay. Anal Biochem 1996;239:70-6.

30. Hu YH, Wang B, Yang J, et al. Synthesis and biological evaluation of 3-arylcoumarin derivatives as potential antidiabetic agents. J Enzyme Inhib Med Chem 2019;34:15-30.

31. Asadipour A, Alipour $M$, Jafari $M$, et al. Novel coumarin-3carboxamides bearing $\mathrm{N}$-benzylpiperidine moiety as potent acetylcholinesterase inhibitors. Eur J Med Chem 2013;70: 623-30.

32. Joubert J, Foka GB, Repsold BP, et al. Synthesis and evaluation of 7-substituted coumarin derivatives as multimoda monoamine oxidase- $B$ and cholinesterase inhibitors for the treatment of Alzheimer's disease. Eur J Med Chem 2017;125: 853-64.

33. Shimizu S, Kanetaka H, Hirose D, et al. Differential effects of acetylcholinesterase inhibitors on clinical responses and cerebral blood flow changes in patients with Alzheimer's disease: a 12-month, randomized, and open-label trial. Dement Geriatr Cogn Disord Extra 2015;5:135-46.

34. Karlsson D, Fallarero A, Brunhofer G, et al. The exploration of thienothiazines as selective butyrylcholinesterase inhibitors. Eur J Pharm Sci 2012;47:190-205.

35. Matos MJ, Viña D, Vazquez-Rodriguez $S$, et al. Focusing on new monoamine oxidase inhibitors: differently substituted coumarins as an interesting scaffold. Curr Top Med Chem 2012;12:2210-39.

36. Kim D, Baik SH, Kang $S$, et al. Close correlation of monoamine oxidase activity with progress of alzheimer's disease in mice, observed by in vivo two-photon imaging. ACS Cent Sci 2016;2:967-75.

37. Lovell MA, Markesbery WR. Oxidative damage in mild cognitive impairment and early Alzheimer's disease. J Neurosci Res 2007;85:3036-40. 